\title{
Further Studies on the Sexuality of the Uredineae.
}

\author{
BY
}

VERNON H. BLACKMAN, M.A., F.L.S.,

Assistant, Department of Botany, British Museum ; Lecturer on Botany, East London College ; formerly Fellow of St. John's College, Cambridge.

AND

HELEN C. I. FRASER, B.SC., F.L.S., Assistant Lecturer on Botany, Royal Holloway College.

With Plates III and IV.

FARLIER studies by one of us (1) have shown that in the aecidium D of Phragmidium violaceum a peculiar process occurs, in which the nucleus of an ordinary vegetative cell migrates into a special 'fertile cell,' which then develops actively and gives origin to a series of binucleate aecidiospores and intercalary cells, the two nuclei always dividing by a process of conjugate division. This fertile cell was considered to be a female cell, and its union with the vegetative cell a 'reduced sexual process' in which the latter cell replaces the now functionless male cell (spermatium).

These further studies were undertaken to ascertain how far this process would explain generally the origin of the conjugate nuclear condition which is known to be constant in the cells of the aecidium which produce the aecidiospore-rows. The development of the typical aecidium with its definite pseudoperidium, and its comparatively deep point of origin in the tissues of the host, obviously required cytological investigation for comparison with that of Phragmidium. For in that genus the aecidium (the so-called caeoma) is of very simple type, consisting merely of a single layer of fertile cells developed directly beneath the epidermis, and bounded only by a few paraphyses; and even these may sometimes be absent.

It was also hoped that further investigation might throw some light on the cytological life-history of the reduced forms which, possessing no aecidium, yet show cells with conjugate nuclei at some stage of development, the paired nuclei fusing sooner or later in the teleutospore.

While this work was in progress a very interesting paper appeared

[Annals of Botany, Vo1. XX. No. LXXVII. January, I906.] 
by Christman (3), in which he showed that in certain forms (Phragmidium speciosum, Caeoma nitens, and Uromyces Caladii) the sexual process was very different from that observed in $P$. violaceum. In the aecidia of these forms fusion in pairs takes place between the uninucleate fertile cells; cells with conjugate nuclei are thus produced, which then undergo a series of rapid divisions and produce the aecidiospores in the usual way.

We have been able to confirm the existence of this type of fusion in the aecidium of one form which we investigated, and there is no doubt that it must be given equal rank with nuclear migration as a method of aecidium development; but we are not able to accept Christman's interpretation of his results. He looks upon the process he observed as a mere conjugation of undifferentiated gametes; and though he comments on two such different types of sexual development occurring in the same genus, Phragmidium, he makes no attempt to bring them into line.

If, however, the view be accepted that the fertile cells of $P$. violaceum represent female gametes, which are now fertilized by vegetative cells instead of by male cells (the now functionless spermatia), it follows that the cells which fuse in $P$. speciosum-since the structure and development of the aecidium is exactly the same in the two cases-also represent female cells, which now conjugate in pairs. By such a very simple interpretation the two processes are reduced to a common term. The two species of Phragmidium are then seen to exhibit merely two different methods of dealing with the same problem-fertilization in the absence of the male cell. In the one case the male cell is replaced by a vegetative cell, in the other by another female cell.

If, on the other hand, Christman's view of the behaviour of $P$. speciosum be accepted, it must also apply to $P$. violaceum, and it leads to the unsatisfactory conclusion that the fertile cells here also represent undifferentiated gametes, which for some obscure reason have given up fusing in pairs, and now fuse with vegetative cells instead.

The view put forward above obviously explains the relation of the two processes throughout the group, and has the further advantage of giving a reasonable explanation of the structure and occurrence of the spermatia, which in Christman's view are left out of account.

That the conjugation of female gametes may take place in the absence of the appropriate male cells is shown clearly by the authors' studies on Humaria granulata (2), where, in the absence of the antheridium, the female nuclei of the ascogonium fuse in pairs.

The forms investigated were Uromyces Poae, Raben., Puccinia Poarum, Niels, and Melampsora Rostrupi, Wagn., for the development of the aecidia, and Puccinia Malvacearum, Mont., Puccinia Adoxae, DC., Uromyces Ficariae, Lév., and Uromyces Scillarum, Wint. 
The material was fixed in Flemming's weaker fluid or in acetic alcohol ( 20 or 25 per cent. sol. of the acid in absolute alcohol). The latter fluid does not fix so well as that of Flemming, but is much more penetrating, and was always used when an air-pump was not available; without the use of such an instrument watery fluids will not satisfactorily fix the portions of leaves. Benda's iron-haematoxylin followed by a one per cent. watery solution of Congo-red, as already described (2), was found the most satisfactory stain.

In addition to the cytological observations mentioned in the earlier paper (1), the general morphology of the aecidium has been investigated by De Bary, Neumann (6), and Richards (7).

\section{Uromyces Poae, Raben.}

This is a heteroecious eu-form with its spermogonial and aecidial stage on Ramunculus Ficaria. Material was obtained in April and fixed in acetic alcohol.

The vegetative mycelium of the Fungus is found ramifying among the cells of the leaf and petiole, and occasionally of the young fruit. The hyphae exhibit single nuclei, usually in separate cells, as was observed earlier by Sapin-Trouffy (8).

The spermogonia appear early on the upper side of the leaf and have the typical flask-shaped structure, being very similar to those of Puccinia graminis. The spermatia (P1. III, Fig. IO) have the large nucleus and the reduced cytoplasm which has been pointed out in the earlier paper (1) as characteristic of these cells throughout the group. They take no part in aecidium development and are, as usual, without apparent function.

The first indication of the young aecidium is a mass of tangled hyphae, which develops directly below the epidermis on the under side of the leaf; in the petiole this mass may be placed a little deeper. The group of hyphae increases in size and soon shows a differentiation into two sharply marked portions, a lower consisting of a mass of closely packed hyphae composed of short, uninucleate cells with dense contents, and an upper consisting of large irregular hyphae which are almost completely empty (Fig. I). The large empty cells seem to be derived, at least in part, from the lower small-celled hyphae with dense contents, for cells cut off from the latter can be seen enlarging and losing their contents.

The nuclei of the cells with granular contents contain in the resting state a very well marked nucleolus, but the chromatin is very small in amount, and both it and the nuclear membrane stain with great difficulty. This nuclear structure is characteristic of all the cells of the aecidium, so that in ordinary lightly stained preparations the nucleus appears as a deeply staining large granule, the nucleolus, surrounded by a light 
area (P1. III, Figs. I-4). It is only in exceptional cases or in material in which the cytoplasm has been much overstained that a nuclear reticulum can be clearly made out (Fig. 8).

As development of the young aecidium proceeds the cells with dense contents become somewhat larger, and their origin from hyphal rows of cells less obvious. The next stage is that among the mass of dense uninucleate cells a few binucleate ones appear, and these have increased somewhat in size (Fig. 2). More and more cells gradually become binucleate and arrange themselves into a definite layer. These binucleate cells are the 'fertile cells' of the aecidium, and it is from them that the rows of aecidiospores and intercalary cells are derived, the fertile cells forming the basal layer of the aecidium (Fig. 7).

Before they become binucleate the fertile cells are not very clearly defined, but at the stage of development, at which some of the cells with dense contents are changing from the uninucleate condition to that with paired nuclei, there can be observed migrations of nuclei from one cell into a cell which is still uninucleate. These nuclear migrations are much more difficult to observe than in the case of Phragmidium violaceum, for the 'fertile cells' are neither well defined when young, nor can progressive stages of development be observed in passing from the periphery to the centre of the aecidium. Thus migrations have to be sought for generally in the mass of mixed uninucleate and binucleate cells such as is found in the stage shown in Fig. 2.

Only a small number of migrations were clearly observed, but there can be little doubt that, as in Phragmidium violaceum (where numerous cases were observed), the condition of conjugate nuclei in the aecidium is normally brought about in this form by a process of nuclear migration into the special fertile cells.

The migrations were of the same type as those observed earlier in Phragmidium, the nucleus becoming very much constricted in its passage through the wall. In the present form, however, the nucleolus, being the only deeply staining portion of the nucleus, is the part that can be traced most easily through the wall. During the process it becomes stretched out into a band-like structure (Figs. $3^{-6}$ ) (often with a characteristic beaked appearance) in the formation of which the chromatin, no doubt, plays a small part.

No signs were observed of the fusion of the fertile cells in pairs as described by Christman, although on the appearance of that author's paper the preparations were carefully re-examined with that object in view.

Owing to the difficulty of distinguishing the fertile cells in the very young state the presence of definite sterile cells, as in Phragmidium, could not be made out with any certainty, although indications of them were observed in a few cases. 
As development of the aecidium proceeds the fertile cells, aecidiosporemother-cells, and spores become arranged in perfectly regular rows, and the hyphae below the aecidium become gradually emptied of their contents, which pass up into the fertile cells (Fig. 7). The intercalary cells are small and disappear early; the division which separates them from the aecidiospores being usually found in the second or third row of cells above the layer of fertile cells.

The development of the pseudoperidium from the outermost layer of 'fertile cells' is well shown in Fig. 7. These pseudoperidial cells exhibit very thick, finely striated walls, and their contents, with the two nuclei, soon become disorganized. In the young state, before it is ruptured, the pseudoperidium stretches like a protecting dome over the more or less hemispherical mass of developing fertile cells and aecidiospores (Fig. 7). The cells of the pseudoperidium appear to represent in this form aborted aecidiospore-mother-cells rather than aecidiospores, for no clear cases of the formation of intercalary cells were observed in them.

Some evidence was obtained in support of Richards' (7) observation that the terminal spores cut off from the central fertile cells (basidia of older authors) form the central part of the pseudoperidium, the peripheral part only being formed by the outermost layer of fertile cells; this point, however, was not investigated in detail.

Various stages of conjugate division (Figs. $9 a-d$ ) were observed in the divisions which cut off the intercalary cells. The small simple spindles and the chromatin masses, without, apparently, any differentiation into chromosomes, were to be seen as described in the earlier paper (1); but in this case the minute size of the chromatin mass as compared with the large nucleolus is very striking.

As in the case of Phragmidium violaceum, fertile cells, and the spores derived from them, were sometimes observed which contained three nuclei, and in very rare cases four nuclei were to be seen. The trinucleate cells were not uncommon, and it was not unusual to observe three or four rows of such cells in one aecidium. Whether these abnormal numbers are due to the division of one or both of the conjugate nuclei, or to a process of multiple fertilization, it is at present impossible to say. It is to be noted that cells with more than two nuclei were observed by Richards (7) in some of the aecidia which he investigated, but Sapin-Trouffy makes no mention of them. The fate of the aecidiospores with more than two conjugate nuclei is also unknown; they might conceivably give rise to a mycelium with, for example, trinucleate cells and bearing trinucleate uredospores and teleutospores, but such has not been met with. It is possible, on the other hand, that they are incapable of germination. 


\section{Puccinia PoARum, Niels.}

The spermogonial and aecidial stages of this heteroecious form are found on the leaves of Tussilago Farfara, the aecidia appearing as round whitish swellings in their very young state. $P$. Poarum is peculiar in having two crops of aecidiae in each year, one in the spring and one in the autumn; also two crops of uredospores and teleutospores arising from the aecidiospores. The material here investigated was obtained in early September.

The aecidia arise somewhat deeper in the leaf tissue than in the case of Uromyces Poae, but their general development is very similar. The fertile cells arise in the same way, though their early stages are even more irregular, and there is the same doubt as to the presence, or absence, of definite sterile cells.

Nuclear migrations (Figs. I 2 and 13 ) of the usual type were observed in connexion with the differentiated fertile cells. It was noticed, however, that paired nuclei were also to be observed at a stage before the differentiation of the fertile layer, or in cells below that layer after its differentiation. This suggested that nuclear migrations might sometimes take place in cells which had not yet differentiated into fertile cells. This view proved to be justified; for besides the ordinary nuclear migrations mentioned above, one case was observed of a nuclear migration from one vegetative cell to another (Fig. 14). The cell so fertilized was just below the layer of fertile cells, and presumably it would either grow up directly into a fertile cell, or it might divide further before giving origin to the definite fertile cells.

We thus have in P. Poarum two types of nuclear migration in connexion with the development of the aecidium: one an ordinary nuclear migration (reduced fertilization) into a fertile (female) cell, the other a less common process, in which a vegetative cell is fertilized in a similar way, and later gives origin to a fertile cell or cells. The latter process is of great interest, for when it occurs the homologue of the female cell is actually fertilized from its very origin. It is as if the prothallial vegetative cells investigated by Farmer, Moore, and Digby (5) should, after fusing, produce an oospore (containing naturally the double number of chromosomes) from which the embryo arose later.

This form also was carefully examined for the fusion described in other cases by Christman (4), but no evidence of such a process could be obtained.

The development of the spores and of the pseudoperidium is the same as that of Uromyces Poae.

Cells with three and with four nuclei were observed in this form also, and a spore-mother-cell of each kind was seen in division (Figs. 15 and I 6 ), showing clearly that in these abnormal cases there is true conjugate division. 
Neither in this case nor in that of Uromyces Poae was any evidence obtained for the origin of the fertile cells from one or several special hyphae, as described for a number of forms by Richards (7). The latter author laid considerable stress on this point at the time, as tending to confirm a relationship between the aecidium and the ascocarp; but the work of recent years, which has so clearly established the fertile cells as independent sexual elements, reduces the exact origin of these cells to a point of little significance. The aecidium we now know is in no sense a definite morphological entity and cannot be compared with the ascocarp.

\section{MELAMPSORA ROSTRUPI, Wagn.}

The aecidial stage of this form occurs on Mercurialis perennis, and before its relation to the Melampsora on Populus was worked out by Rostrup it was known as Caeoma Mercurialis. The aecidium is of particular interest, for, like that of the Melampsoras generally, it is without a pseudoperidium, and, therefore, of the same type as that of Phragmidium.

A definite row of uninucleate fertile cells with sterile cells above is developed close beneath the epidermis just as in Phragmidium. Sometimes, however, it is, apparently, not a superficial cell of the mycelium which develops into the fertile and sterile cells, but a slightly lower cell; so that, later, one or two layers of small crushed cells are found above the sterile cells. The fertile cells become binucleate and then develop and produce rows of aecidiospores and intercalary cells in the typical way.

No evidence of nuclear migration could be observed in these cases, but the greater width of the binucleate cells giving origin to the aecidiospore rows as compared with that of the uninucleate fertile cells was noticeable; as was also the fact that two sterile cells could sometimes be clearly distinguished above the young binucleate cells (Fig. 17). This indicated that the conjugate nuclear condition was brought about by the fusion of cells as described by Christman. Owing to the age of the material the earliest stages of fusion were not observed, but very clear evidence of this fusion was obtained from later stages. In these cases the remains of the partition wall in the lower part of the cell were to be seen exactly as described by Christman (Figs. I 7 and I 8 ).

In Melampsora Rostrupi, then, we have the other type of reduced fertilization in which the fertile (female) cells fuse in pairs.

The cells of the aecidium produced in this way can no longer be termed 'fertile cells,' since they are the product of two such cells. A single term is, however, obviously convenient for the cells, whatever their origin, which give rise to the rows of aecidiospore and intercalary cells. As the 
term basidia of the older workers is no longer applicable, they may simply be termed the basal cells of the aecidium, since they are the cells at the base of the special cell-rows.

\section{Puccinia Malvacearum, Mont.}

As is well known this parasite is one of the lepto-forms, i.e. there is only one kind of spore, the teleutospore, and this germinates in the sorus immediately on reaching maturity. The whole life-cycle is thus completed in a very short time, the teleutospore sorus beginning to appear about twelve days after infection.

As stated by Sapin-Trouffy the vegetative mycelium contains single nuclei. The first indication of the formation of a teleutospore sorus is the development of a tangled mass of uninucleate-celled hyphae, which is often more regular towards its edge (Fig. 19). Then directly on this mass hyphae with conjugate nuclei arise, and these usually produce an irregular mass of binucleate hyphae, on which arise the special cells that are later to give origin directly to the teleutospores (Fig. 20). These special cells produce one or more teleutospores (Figs. 2I and 22), and are very similar, though smaller in size, to the special cells described in an earlier paper for Gymnosporangium clavariaeforme.

Very careful search failed to reveal the exact method by which the transition from the single to the conjugate nuclear condition is brought about. The smallness of the cells and nuclei, and the absence of any regular row or group of cells-such as are found in the aecidia-on which attention can be concentrated in the hunt for nuclear migrations or cell-fusions, render the task of elucidating such a point almost hopeless. That the change of nuclear condition takes place at several different points in connexion with each sorus, and not once for all, is indicated by the general distribution of the binucleate hyphae which first appear.

Whether the conjugate condition of the nuclei is the result of either of the processes observed in the aecidium, or whether there is a still simpler process in which two sister nuclei themselves become conjugate in a cell, must remain unsettled. It must be remembered, however, that nuclear migration between vegetative cells has been seen to occur in P. Poarum. It is also interesting to note that, just as in the aecidium, we find, in connexion with teleutospore-formation, a certain number of abnormal cells and spores which show three nuclei (Figs. 22 and 23). The similarity of abnormality may perhaps be taken as indicating a similarity in the methods by which the conjugate nuclear condition is brought about in the aecidium and young teleutospore sorus respectively. 
Puccinia Adoxae, DC. and Uromyces Scillarum, Wint.

In these two micro-forms, in which the life-history is similarly reduced to its simplest state, young teleutospore sori were examined in early spring. In both these cases it was found that the general vegetative mycelium showed conjugate nuclei (Figs. 24 and 25 ).

In these cases, then, the change to the conjugate condition (i.e. the process of reduced fertilization) must take place very early, and the point at which it occurs can only be discovered by the careful investigation of material from the stage of infection by the sporidium.

The commonness of the binucleate condition of the sporidium at the time of infection might suggest that, in the two cases in question, the conjugate condition starts in the sporidium itself. This, of course, is possible, but it does not seem probable; for on the one hand there is no evidence that sister nuclei ever become conjugate in this simple way, and on the other hand, it has been shown in several cases that the two nuclei in the sporidium are not conjugate, but are merely the result of a precocious nuclear division to be followed later by a cell-division which leads to their separation (see discussion in earlier paper, (1) p. 354). It is much more probable that the conjugate condition is produced soon after infection by nuclear migration, or cell-fusion, between vegetative cells.

\section{UROMYCES FICARIAE, Lév.}

In this micro-form (which, however, sometimes exhibits a few uredospores among the teleutospores), Sapin-Trouffy describes the hyphae generally as being binucleate, so that it would appear to belong to the same category as the two forms just described. The form is not a favourable one for investigation, but from our observations the general mycelium appears to exhibit single nuclei, but the mass of mycelial hyphae round about the teleutospore sorus, as well as those directly connected with teleutospore formation, appear to have conjugate nuclei (Fig. 26). Thus the haustorium in a host-cell close to the teleutospore mass shows clearly two nuclei (Fig. 27).

Though it is difficult to make sure on this point, it is probable that we have in this form a condition somewhat intermediate between that of Puccinia Malvacearum and P. Adoxae; for while the conjugate nuclei appear to arise only in connexion with the teleutospores, yet they arise earlier than in the first-mentioned form, and produce a general mycelium of which part is vegetative and part only teleutospore-forming.

The existence of young teleutospores with three nuclei (Fig. 26), in this form, also suggests that the transition to the conjugate nuclear condition has only just taken place. Cells with abnormal numbers of 
nuclei were not to be seen in Puccinia Adoxae and Uromyces Scillarum, and, as far as observations go, seem only to occur in connexion with such a transition process.

\section{General Conclusions.}

The conjugate nuclear condition of the fertile cells (basidia of older authors) of the aecidium is mainly the result of one of two processes. In the one case, there is a process of nuclear migration from a vegetative cell into a fertile cell (female cell); this has been observed in Uromyces Poae and Puccinia Poarum, as well as in Phragmidium violaceum, where it was first described (1). In the other case the fertile cells fuse in pairs, and thus the conjugate nuclear condition arises; this process was first observed by Christman (4) in Phragmidium speciosum, Caeoma nitens, and Uromyces Caladii, and is described for Melampsora Rostrupi in the present paper.

These two processes are to be considered as merely two different types of reduced fertilization which have replaced the normal fertilization in the absence of the normal male cells (spermatia). In the one case the female cell fuses (partially) with a vegetative cell, in the other case two female cells fuse together (vide supra, p. 36).

While in $U$. Poae nuclear migration seems to take place only into the fertile cells of the aecidium, in Puc. Poarum a small number of migrations appear to take place between vegetative hyphae also, either below the layer of fertile cells or before such cells have become differentiated. The conjugate nuclear condition in these cases is thus started before the differentiation of the cells which represent the female cells.

The basal cells of the aecidium may thus arise by the fertilization of a fertile (female) cell by a vegetative cell, by the conjugation of two fertile (female) cells or (rarely) as the product of an undifferentiated vegetative cell which has earlier undergone a process of fertilization.

This condition, described in the case of Puc. Poarum, leads on very easily to that found in Puc. Malvacearum, where there are no female cells, and the change to the conjugate nuclear condition takes place at a different point in the life-cycle, without the development of any specially differentiated structures, being found only in connexion with the vegetative hyphae, just before the formation of the teleutospores. From this point it is a short step to the condition found in other forms (Puccinia Adoxae, Uromyces Scillarum), where the simple and reduced fertilization process takes place at some earlier point in the life-cycle without apparent relation to the development of the teleutospores.

It is easy to understand that directly the primitive and 'external' 
fertilization by means of spermatia was replaced by a simpler 'internal' fertilization, there would no longer be any bar to the shifting of the reduced sexual process to another point in the life-history. The Uredineae would appear to be a group in which the exact point at which the reduced sexual process (that has replaced in phylogeny the normal one) occurs is not perfectly fixed; though when the homologues of the female cells are present it mainly takes place in connexion with them. The fertilization, however, always occurs before the formation of the first spore-form after the sporidia, so that aecidiospores, uredospores, and teleutospores always show conjugate nuclei.

It is possible that an aecidium-bearing form may be found in which the nuclei become conjugate before aecidium formation, so that all the fertile cells will be binucleate from their first origin; such a case will only be an exaggeration of the condition found in Puccinia Poarum.

Investigation of the typical aecidium confirms the view put forward earlier (1) that it, like the simpler aecidium (caeoma), is to be considered as a sorus of female reproductive organs; in which, however, the outer layers of spores or spore-mother-cells have become sterilized to form the pseudoperidium.

The function of the pseudoperidium is, no doubt, protective, and its development in the typical aecidium is probably related to the deeper point of origin of that structure as compared with the sub-epidermal origin of the caeoma. The latter is to be considered as the more primitive type from which the typical aecidium has been derived.

A study of the reduced forms without aecidia shows clearly that these forms also exhibit an alternation of generations. The transition from the gametophyte to the sporophyte is, however, obscured in these forms owing to the fact that it takes place in an apogamous ${ }^{1}$ way. The exact nature of the apogamy is yet unknown, but it is obviously the result of the interaction of undifferentiated vegetative cells or nuclei; and is a further stage of reduction of the process observed in the aecidium. In the reduced forms also the point of the life-cycle at which it occurs is not exactly fixed.

The transition from the sporophyte to the gametophyte (i.e. reduction) is as clear in the reduced as in the other forms, for it takes place in the teleutospore, which is present in all forms except the very aberrant genus, Endophyllum.

The gametophyte stage with single nuclei may be very well marked even in the reduced forms, or it may be inconspicuous, as is the case in Uromyces Scillarum and Puccinia Adoxae, where possibly it consists of little more than the promycelium. This stage, however, always passes over into the

1 The term apogamy is used for want of a better one, but it is hardly satisfactory when applied to cases in which there is a fusion or association of nuclei ( $2 \mathrm{~A}$ ). 
sporophytic stage with conjugate nuclei before the occurrence of spore formation.

The sporophyte stage, with its three kinds of spores, is always very well marked in the forms with the full life-cycle, but in forms like Puccinia Malvacearum it is represented only by a few generations of cells with conjugate nuclei.

The actual chromosome-reduction no doubt takes place during the first division in the promycelium, but as the fusion of nuclei in the

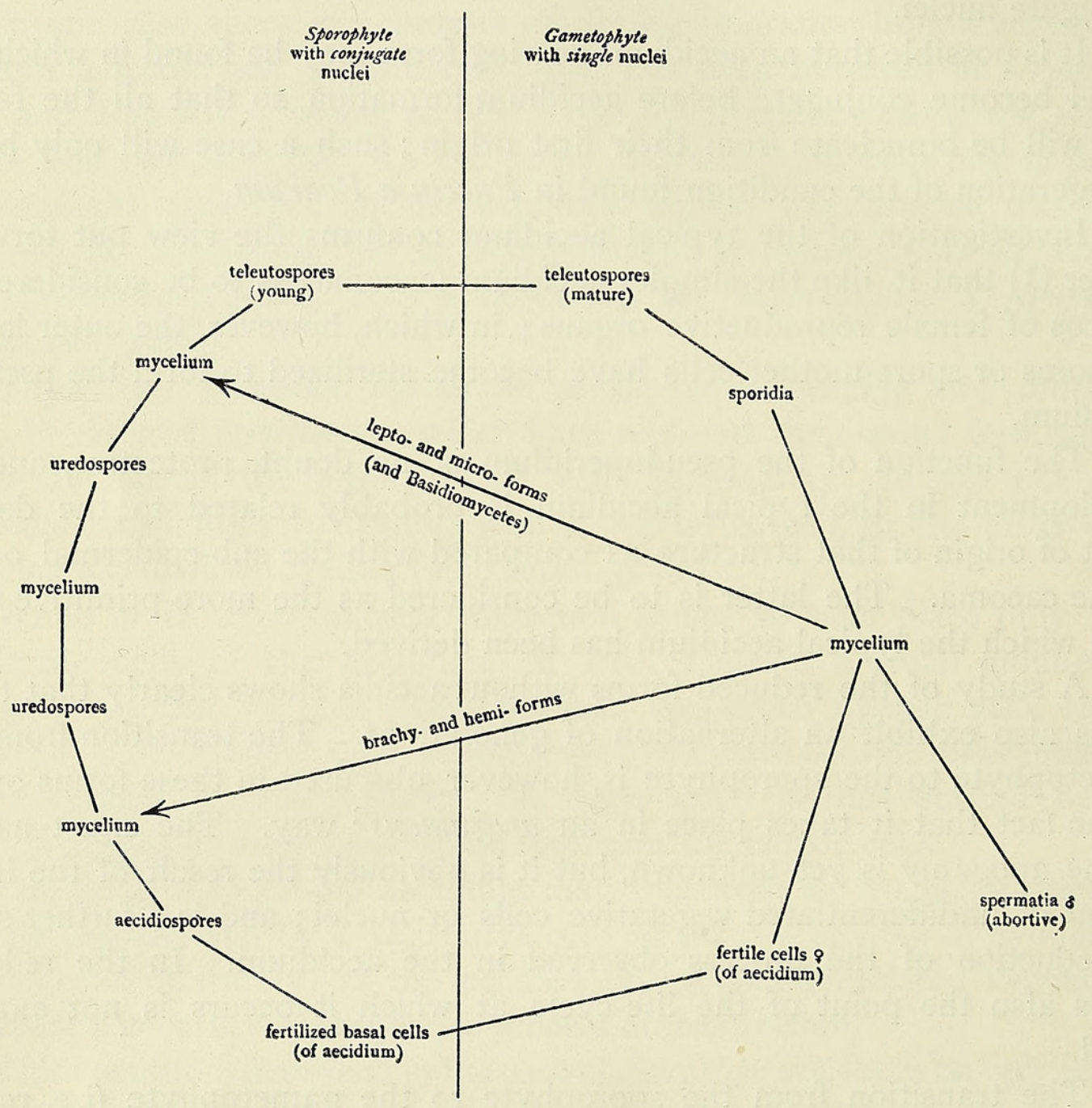

teleutospore is clearly the preliminary to reduction it is convenient to make that fusion the starting-point of the gametophyte.

In the -opsis forms, which are not indicated in the diagram above, the mycelium arising from the aecidiospores gives origin directly to teleutospores.

The Basidiomycetes have clearly the same general and cytological life-history as the lepto- and micro-forms among the Uredineae, as pointed out earlier (1). In this group neither the method nor the exact point 
at which the conjugate condition arises has yet been made out, but according to some recent work of Miss Nichols ${ }^{1}$ the point at which the transition takes place appears, in this group also, to be different for different forms.

A diagram is given to exhibit the general and cytological life-history of the various forms.

1 Trans. Wiscon. Acad. Sci. xv, 1905. This paper has not yet been seen, but it is quoted by Harper in an important work (Sexual Reproduction and the Organization of the Nucleus in certain Mildews) which was received too late to allow of its being considered in the present article.

\section{LIST OF PAPERS.}

1. Blackman, V. H.: On the Fertilization, Alternation of Generations, and general Cytology of the Uredineae. Ann. Bot., xviii, 1904, p. 323.

2. - Congo-Red as a Stain for Uredineae. New Phytol., iv, I905, p. I 73.

2 A. - : On the Relation of Fertilization, 'Apogamy,' and 'Parthenogenesis.' New Phytol., iii, I904, p. 149.

3. - and Fraser, H. C. I.: On the Sexuality and Development of the Ascocarp in Humaria granulata. Proc. Roy. Soc., Ser. B, lxxvii, 1906, in the press.

4. Christman, A. H. : Sexual Reproduction of the Rusts. Bot. Gaz., xxxix, 1905, p. $26 \%$.

5. Farmer, J. B., Moore, J. E., and Digby, L.: On the Cytology of Apogamy and Apospory. Proc. Roy. Soc., lxxi, 1903 , p. 453.

6. Neumann, R.: Ueber die Entwickelungsgeschichte der Aecidien u. Spermogonien der Uredineen. Hedwigia, xxxiii, 1894, p. 346.

7. Richards, H. M.: On some points in the Development of Aecidia. Proc. Amer. Acad. of Arts and Sci., xxxi, 1896, p. 255 .

8. Sapin-Trouffy, P.: Recherches histologiques sur la famille des Urédinées. Le Botaniste, $5^{\circ}$ série, 1896, p. 59 . 


\title{
DESCRIPTION OF PLATES III AND IV.
}

\author{
Illustrating the paper by Mr. Blackman and Miss Fraser on the Uredineae.
}

Figs. I-IO. Uromyces Poae.

Fig. I. Early stage of development of aecidium beneath a stoma; a group of empty hyphae is seen above, and a mass of hyphae with uninucleate cells below. $\times 620$.

Fig. 2. Later stage of development in which a few of the uninucleate cells have become binucleate; a nuclear migration is visible on the left. $\times 530$.

Figs. 3-6. Examples of nuclear migrations into fertile cells. $\times \mathbf{I} 35^{\circ}$.

Fig. 7. Aecidium just before it breaks through the epidermis; a few aecidiospores are already fully formed, the contents of which stain very deeply as if they had become disorganized. The yet unbroken pseudoperidium is very distinct. $\times 620$.

Fig. 8. Nucleus of aecidiospore-mother-cell, showing chromatin reticulum. $\times 1900$.

Figs. $9 a-d$. Stages of conjugate division. $\times 1900$.

Fig. 10. Spermatia. $\times$ I900.

Figs. II-I6. Puccinia Poarum.

Fig. Ir. View of the mass of hyphae forming young aecidium; only a small portion is drawn, starting from just below the epidermis (on the left) and reaching to the base of the mass (on the right). Cells with conjugate nuclei are visible at the base of the mass. $\times 1350$.

Fig. I2. Migration into fertile cell. $\times$ I 350 .

Fig. I3. Migration from vegetative cell into fertile cell above. $\times 135^{\circ}$.

Fig. I4. Migration between two ordinary hyphae. $\times$ I $35^{\circ}$.

Fig. I 5. Early stage of division of cell with three conjugate nuclei. The three chromatin masses on their simple spindles and the three nucleoli are clearly visible. $\times 1900$.

Fig. 16. Later stage of division of cell with four conjugate nuclei. $\quad \times 1900$.

Figs. I 7 and 18. Melampsora Rostrupi.

Fig. I7. Two aecidiospore forming cells of young aecidium. The left-hand cell shows the remains of the partition wall indicating its origin by fusion; above it is an aecidiospore-mother-cell in division. The right-hand cell has two sterile cells side by side above it, which also point to its origin by fusion. $\times 135^{\circ}$.

Fig. I8. Another aecidiospore-forming cell showing its origin by fusion; two layers of disorganizing cells are visible above the aecidiospore-mother-cell. $\times$ I $35^{\circ}$.

Figs. 19-23. Puccinia Malvacearum.

Fig. 19. Uninucleate hyphae growing up beneath epidermis of host to form teleutospore mass. $\times \mathrm{I} 350$.

Fig. 20. Young teleutospore mass showing young undivided spores arising from a group of binucleate cells; a cell on the right is trinucleate. $\times$ I 350 .

Fig. 2I. Cell with conjugate nuclei giving origin to two telentospores; the one on the right has already divided, that on the left is still unicellular, $x \mathrm{I} 35^{\circ}$.

Fig. 22. Young trinucleate teleutospore arising from trinucleate cell; the cell below also shows three nuclei. $\times$ I 350 .

Fig. 23. Young trinucleate teleutospore before division. $\times$ I350.

Figs. 24 and 25. Puccinia Adoxae.

Fig. 24. View of young telentospore mass showing the binucleate condition of both the teleutospores and the general mass of mycelium. $\times 430$.

Fig. 25. Two vegetative hyphae showing the binucleate condition. $\quad \times 1900$.

Figs. 26 and 27. Uromyces Ficariae.

Fig. 26. Young teleutospore sorus developing beneath the epidermis; several of the teleutospores are trinucleate. $\times 430$.

Fig. 27. Cell of host showing binucleate haustorium close to nucleus. $\times$ I 900. 
Annals of Botany,
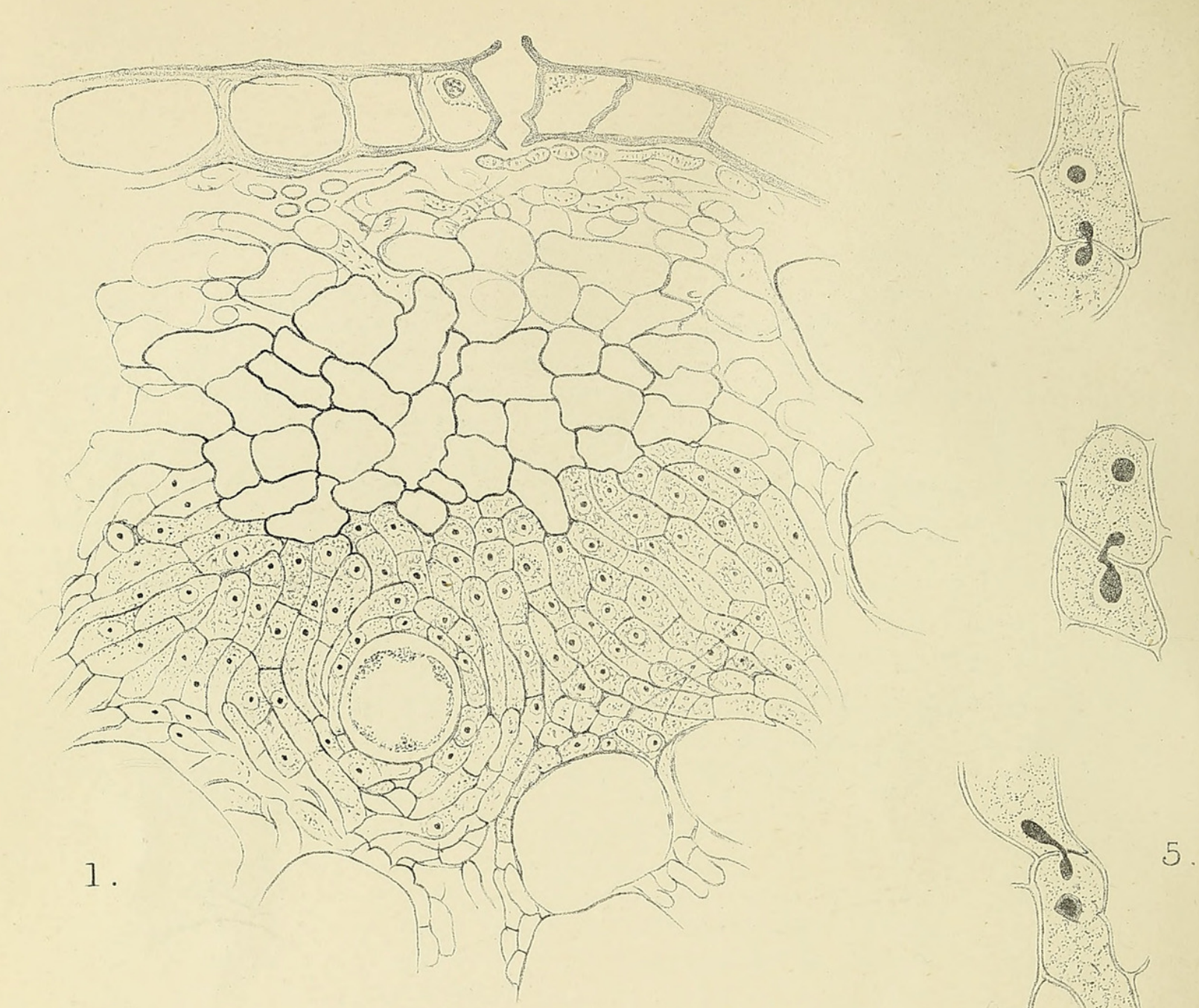

4
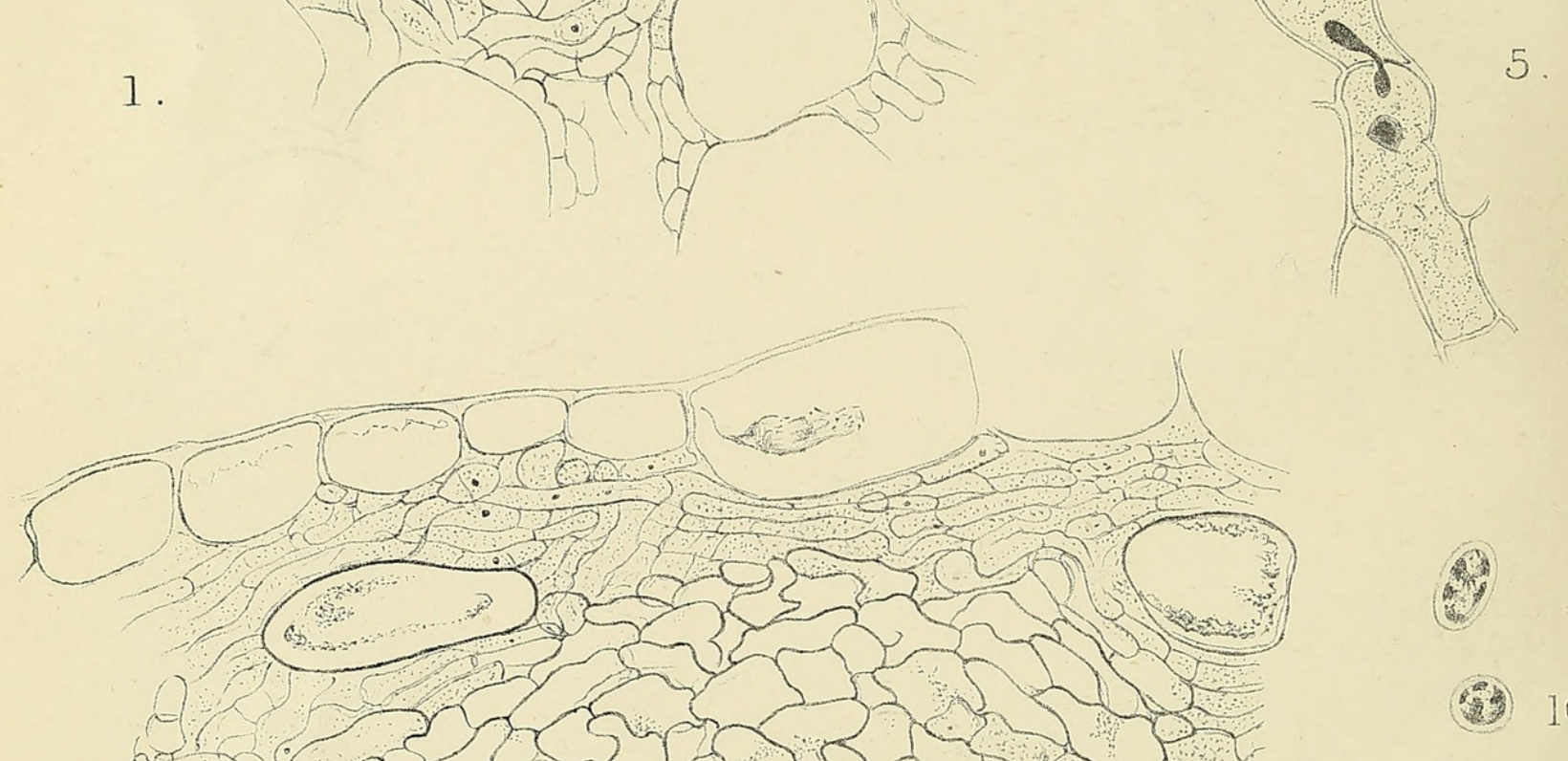

(9) 10

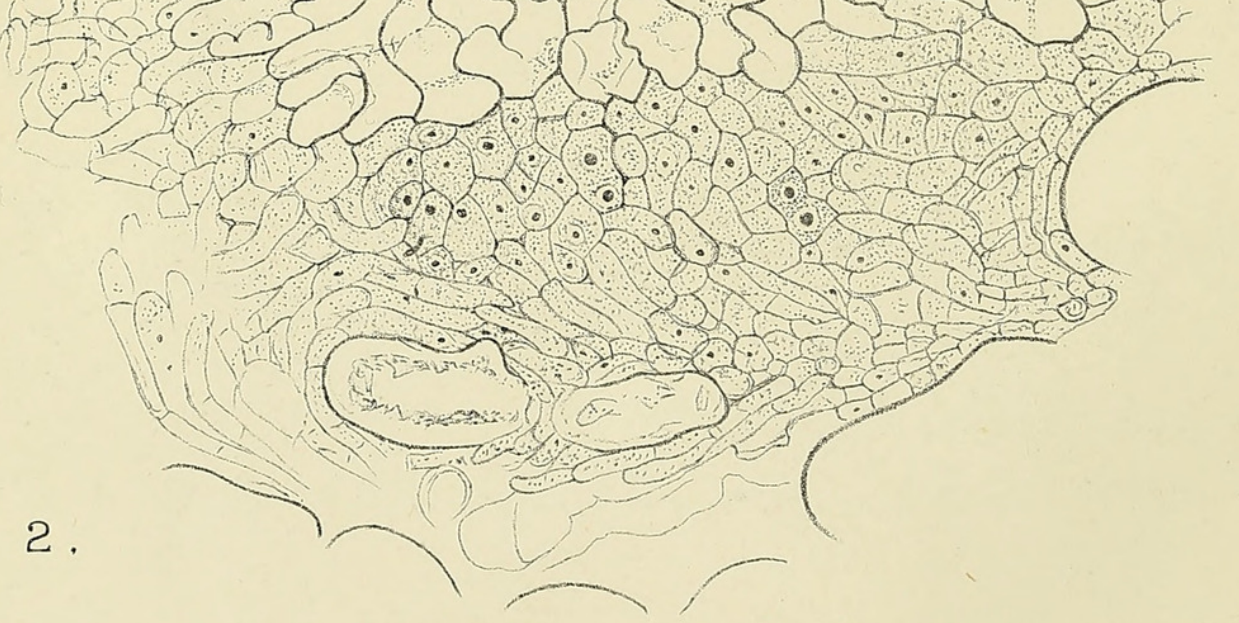

(4)

P. Highley, del

BLACKMAN AND FRASER, - UREDINEAE. 

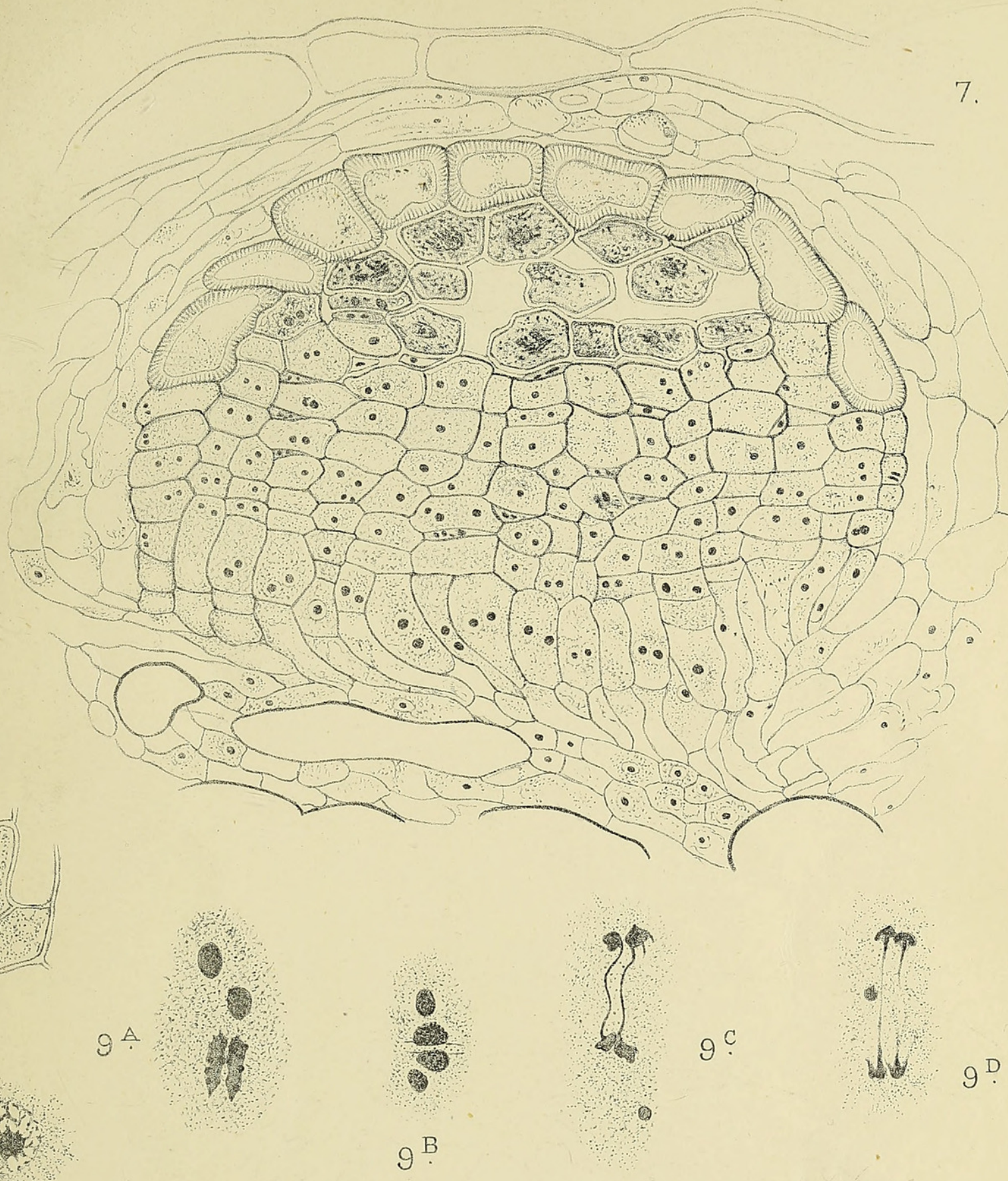

8

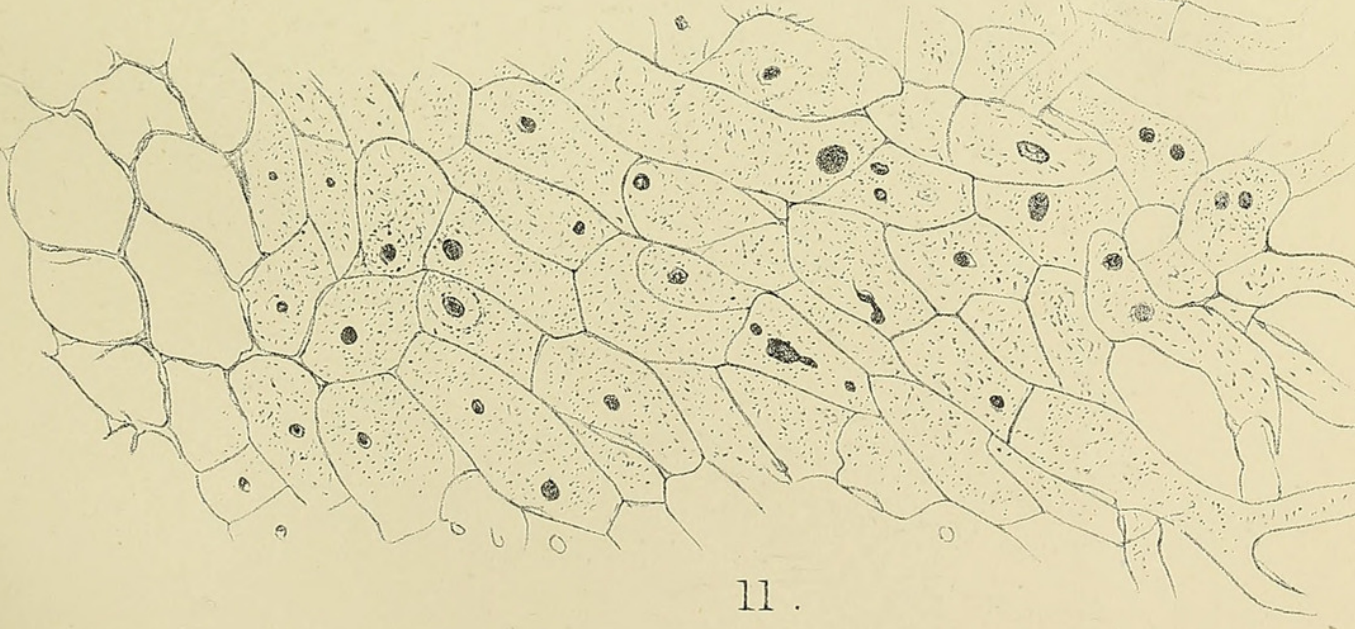



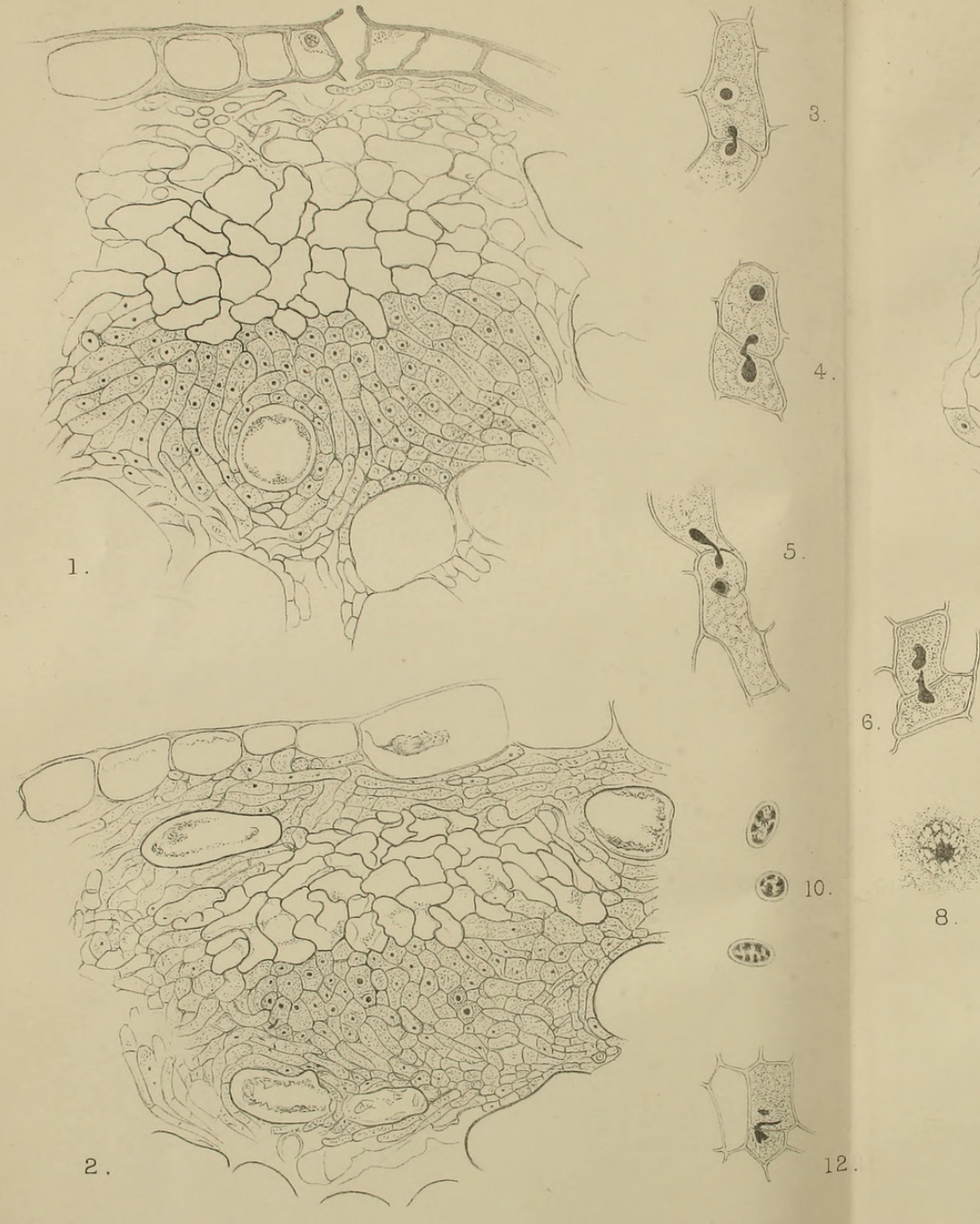

(3) 10

(4its

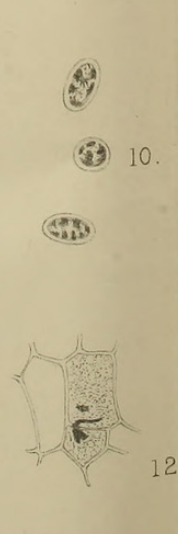

P. Highloy, del.

BLACKMAN AND FRASER, - UREDINEA.

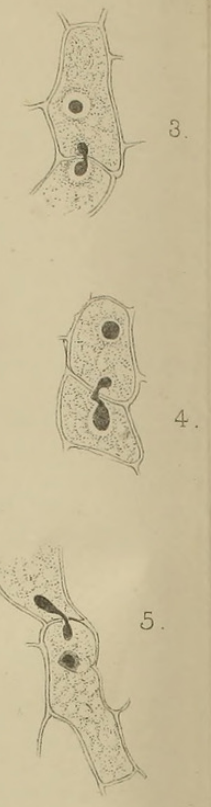

18

8.
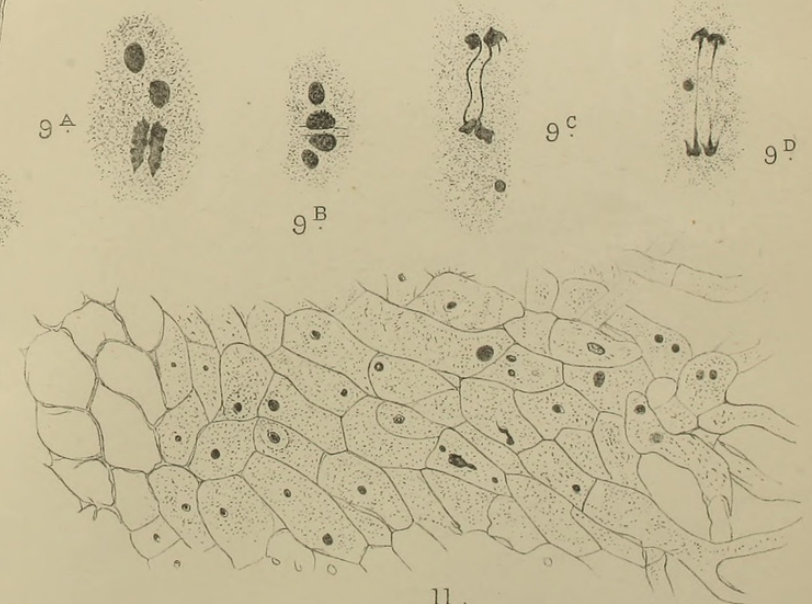

Huth, Lithr Londen 
Annals of Botany,
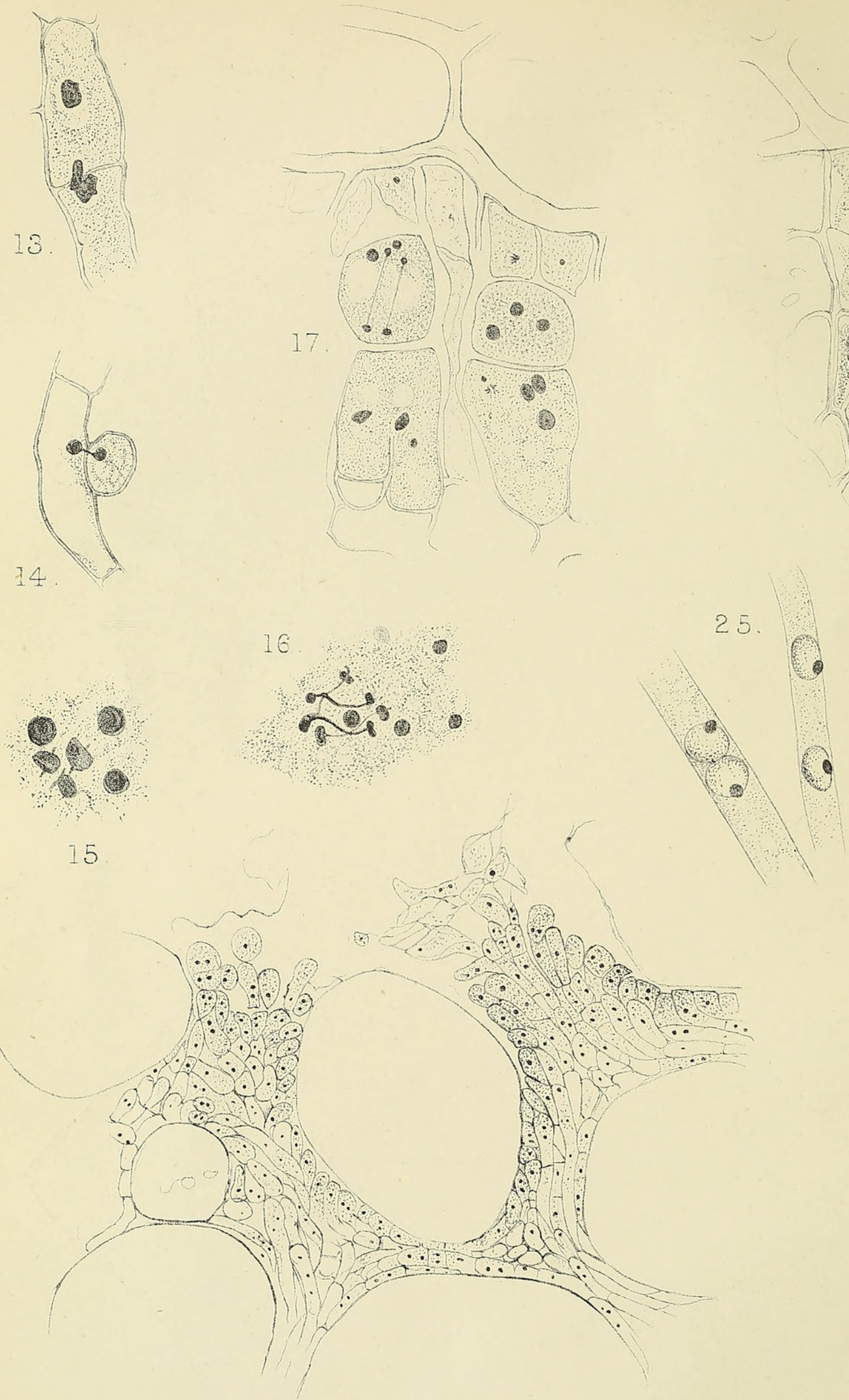


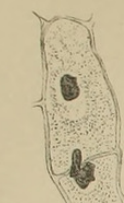

13.
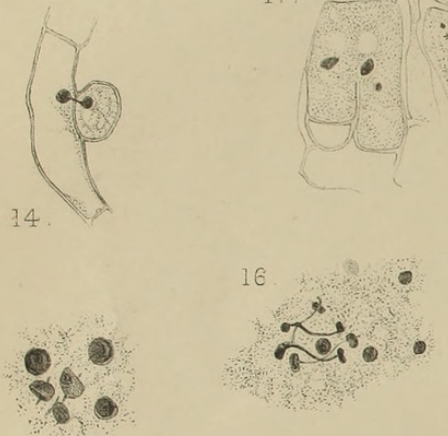

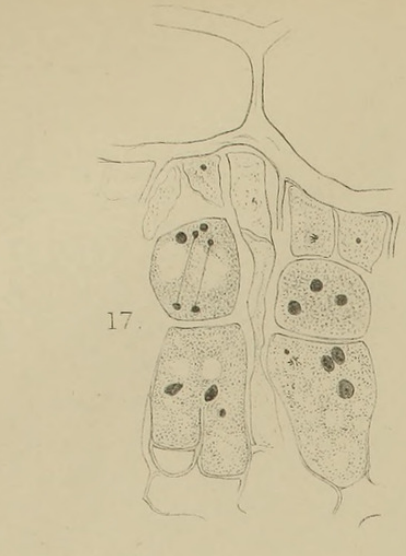

15

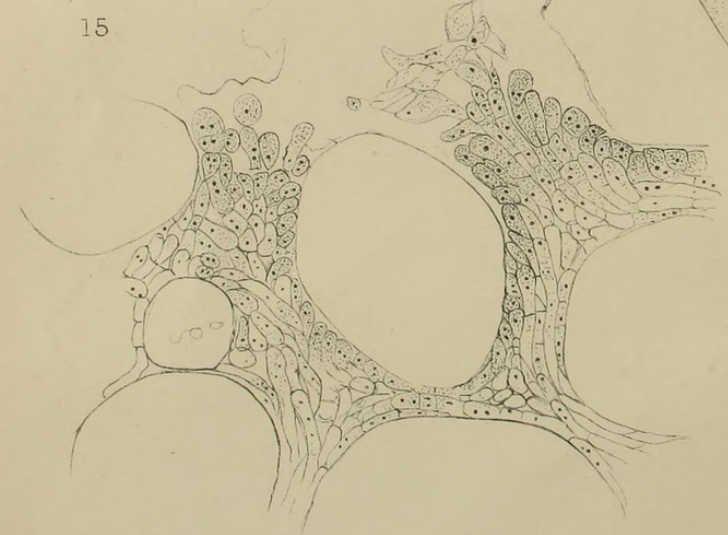

24.
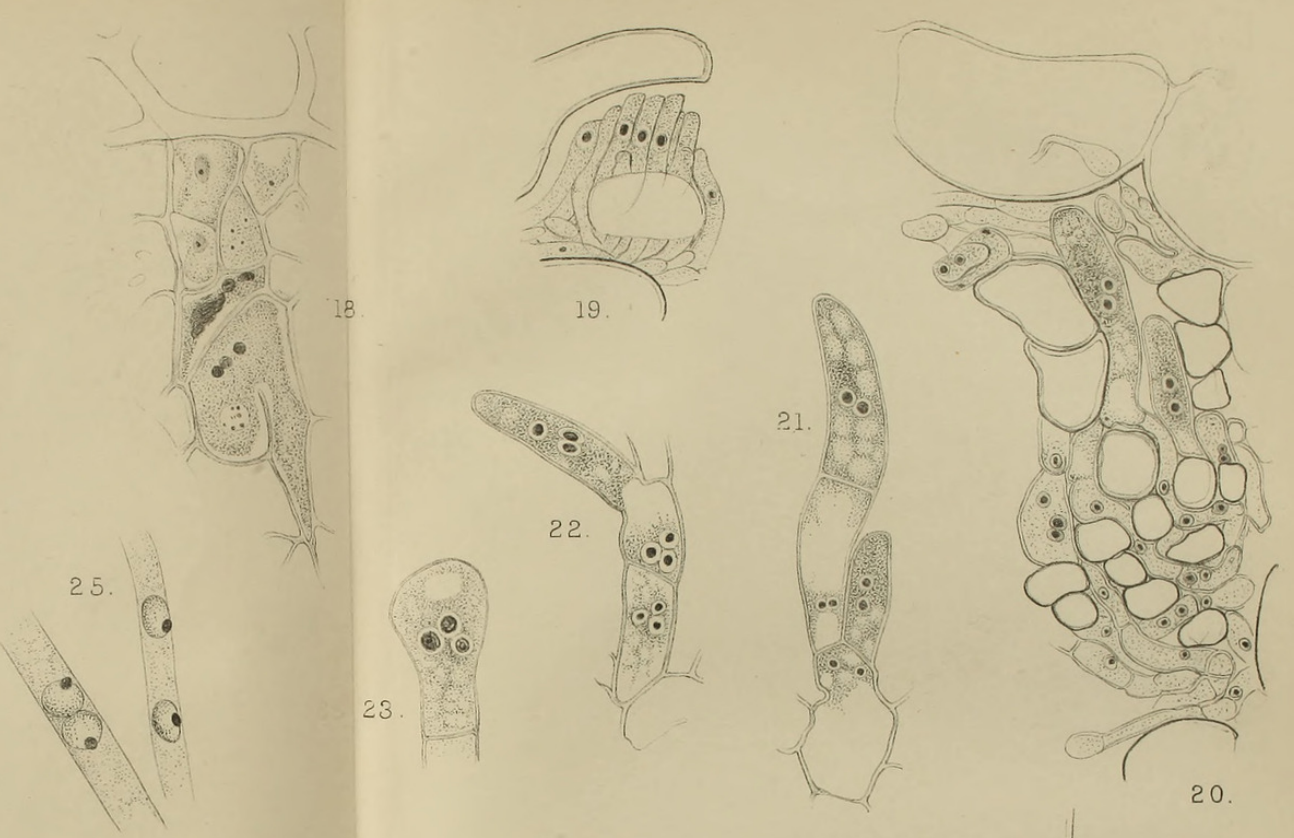

26.
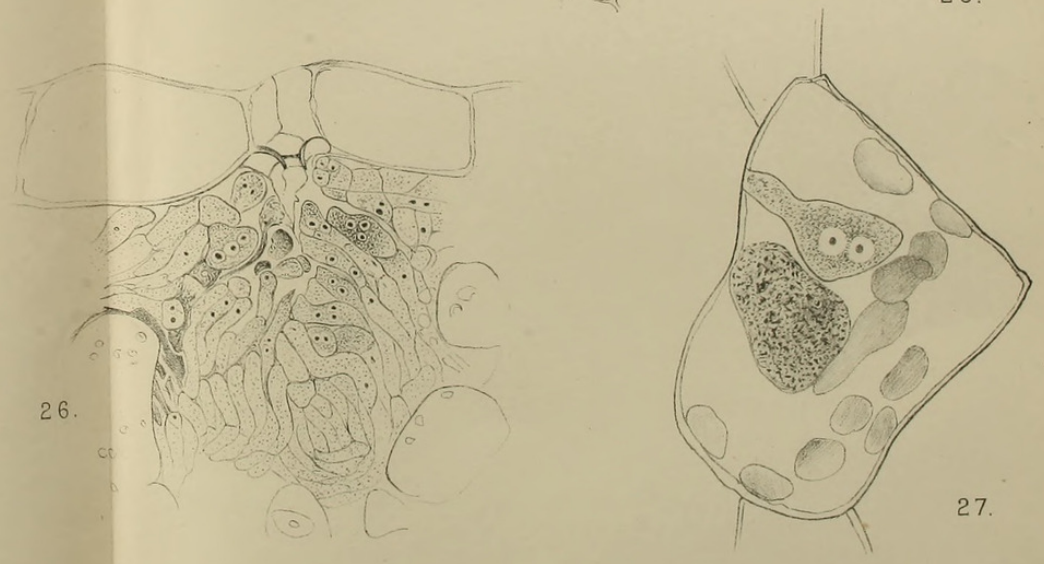

Huth, Lithr London 


\section{$2 \mathrm{BHL}$ Biodiversity Heritage Library}

Blackman, Vernon H. and Gwynne-Vaughan, H. C. I. 1906. "Further studies on the sexuality of the Uredineae." Annals of botany 20, 35-48. https://doi.org/10.1093/oxfordjournals.aob.a089081.

View This Item Online: https://www.biodiversitylibrary.org/item/234848

DOI: https://doi.org/10.1093/oxfordjournals.aob.a089081

Permalink: https://www.biodiversitylibrary.org/partpdf/318820

\section{Holding Institution}

Smithsonian Libraries

\section{Sponsored by}

Biodiversity Heritage Library

\section{Copyright \& Reuse}

Copyright Status: Not in copyright. The BHL knows of no copyright restrictions on this item.

This document was created from content at the Biodiversity Heritage Library, the world's largest open access digital library for biodiversity literature and archives. Visit BHL at https://www.biodiversitylibrary.org. 